\title{
KINERJA GURU PKN YANG BERSERTIFIKAT DALAM PELAKSANAAN TUGAS PEMBELAJARAN (STUDI PADA SMK NEGERI 4 KENDARI)
}

\author{
Abdul Syaban ${ }^{1}$, Nerlin $^{2}$ \\ Jurusan Pendidikan Pancasila dan Kewarganegaraan \\ Fakultas Keguruan dan Ilmu Pendidikan \\ Universitas Halu Oleo \\ Email: abdulsyaban1992@gmail.com¹, nerlin@gmail.com²
}

\begin{abstract}
Abstrak: Penelitian ini bertujuan: 1) untuk mengetahui dan menganalisis kinerja guru PKn yang bersertifikat dalam pelaksanaan tugas pembelajaran di SMKNegeri 4 Kendari; dan 2) untuk mengetahui dan menganalisis faktor-faktor yang mempengaruhi kinerja guru PKn yang bersertifikat dalam pelaksanaan tugas pembelajaran di SMKNegeri 4 Kendari. Penelitian ini dilaksanakan di Sekolah Menengah Kejuruan (SMK) Negeri 4 Kendari. Jenis atau sifat penelitian yang digunakan adalah deskriptif kualitatif. Responden penelitian sebanyak 3 orang guru PKn, dan Informan penelitian sebanyak 3 orangyang terdiri Kepala sekolah SMKNegeri 4 Kendari, wakil Kepala Sekolah (SMK) Negeri 4 Kendari dan Pengawas guru PKn SMK Negeri 4 Kendari. Teknik Pengumpulan data terdiri dari observasi langsung, wawancara dan dokumentasi. Data dianalisis secara deskriptif kualitatif. Hasil penelitian menunjukan bahwa kinerja guru PKn yang bersertifikat dalam pelaksanaan tugas pembelajaran SMK Negeri 4 Kendari sesuai PerMenpan No. 16 tahun 2009 yaitu perencanaan pembelajaran sudah sangat baik, sedangkan dalam pelaksanaan kegiatan pembelajaran dan penilaian atau evaluasi pembelajaran masuk dalam kategori baik. Sedangkan faktor-faktor yang mempengaruhi kinerja guru PKn terbagi 2 faktor yaitu faktor internal dan faktor eksternal. Faktor internal terdiri dari kemampuan (ability), motivasi (motivation), tingkat pendidikan guru, kondisi fisik (kesehatan). Sedangkan faktor eksternalterdiri dariiklim sekolah, kepemimpinan kepala sekolah dan sarana dan prasarana.
\end{abstract}

\section{Kata Kunci : Kinerja Guru, Bersertifikat, Pembelajaran}

\section{PENDAHULUAN}

Guru merupakan komponen yang sangat berpengaruh terhadap terciptanya proses dan hasil pendidikan yang berkualitas. Oleh karena itu upaya perbaikan apapun yang coba dilakukan untuk meningkatkan kualitas pendidikan tidak akan memberikan sumbangan yang signifikan tanpa di dukung oleh guru yang profesional dan berkualitas. Sebagai pengajar atau pendidik guru merupakan salah satu faktor utama yang sangat menentukan keberhasilan dalam pendidikan. Kinerja guru dalam perencanaan pembelajaran, pelaksanaan kegiatan pembelajaran dan penilaian atau evaluasi pembelajaran, merupakan faktor utama dalam pencapaian tujuan pengajaran, keterampilan penguasaan proses pembelajaran ini sangat erat kaitannya dengan tugas tanggung jawab guru sebagai pengajar dan pendidik. Guru sebagai tenaga profesional dan berkualitas yang memegang peran sentral tersebut telah diamanatkan dalam Undang-Undang Republik Indonesia Nomor 14 Tahun 2005, pada pasal 1 dinyatakan bahwa guru adalah pendidik profesional dengan tugas utama mendidik, mengajar, membimbing, mengarahkan, melatih, menilai, dan mengevaluasi peserta didik pada pendidikan anak usia dini jalur pendidikan formal, pendidikan dasar dan pendidikan menengah. Sedangkan pada pasal 8 disebutkan bahwa guru wajib 
memiliki kualifikasi akademik, kompetensi, sertifikat pendidik, sehat jasmani dan rohani, serta memiliki kemampuan untuk mewujudkan tujuan pendidikan nasional.

Pasal-pasal dalam undang-undang tersebut telah menjelaskan secara tegas bahwa guru harus mampu membangun kredibilitas dan kinerjanya secara baik sesuai harapan dari stakeholdersnya demi tercapainya tujuan pendidikan nasional. Menurut Prawirosentoso (Jasmani Asf \& Syaiful Mustofa, 2013 : 153) bahwa kinerja merupakan hasil kerja yang dapat dicapai oleh seorang atau sekelompok orang dalam suatu organisasi, sesuai dengan wewenang dan tanggung jawab masing-masing. Hal yang sama juga dikatakan oleh Mangkunegara (Jasmani Asf \& Syaiful Mustofa, 2013 : 154) bahwa kinerja adalah hasil kerja secara kualitas dan kuantitas yang dicapai seorang guru dalam melaksanakan tugasnya sesuai dengan tanggung jawab yang diberikan kepadanya.

Berkenaan dengan standar kinerja guru Kusmianto (Sahertian, 1997: 49) menjelaskan bahwa standar kinerja guru itu berhubungan dengan kualitas guru dalam menjalankan tugasnya seperti: (1) bekerja dengan siswa secara individual, (2) persiapan dan perencanaan pembelajaran, (3) pendayagunaan media pembelajaran, (4) melibatkan siswa dalam berbagai pengalaman belajar, dan (5) kepemimpinan yang aktif dari guru. Undang-Undang Republik Indonesia No. 20 Tahun 2003 tentang Sisdiknas pasal 39 ayat (2), menyatakan bahwa pendidik merupakan tenaga profesional yang bertugas merencanakan dan melaksanakan proses pembelajaran, menilai hasil pembelajaran, melakukan pembimbingan dan pelatihan serta melakukan penelitian dan pengabdian kepada masyarakat, terutama bagi pendidik pada perguruan tinggi. Keterangan lain menjelaskan dalam UU No. 14 Tahun 2005 Bab IV Pasal 20 (a) tentang Guru dan Dosen menyatakan bahwa standar prestasi kerja guru dalam melaksanakan tugas keprofesionalannya, guru berkewajiban merencanakan pembelajaran, melaksanakan proses pembelajaran yang bermutu serta menilai dan mengevaluasi hasil pembelajaran. Tugas pokok guru tersebut yang diwujudkan dalam kegiatan belajar mengajar merupakan bentuk kinerja guru.

Menurut Davies (1987 : 35-36) mengatakan bahwa seorang mempunyai empat fungsi umum yang merupakan ciri pekerja seorang guru yakni: 1) Merencanakan, yaitu pekerjaan seorang guru menyusun tujuan belajar; 2) Mengorganisasikan, yaitu pekerjaan seorang guru untuk mengatur dan menghubungkan sumber-sumber belajar sehingga dapat mewujudkan tujuan belajar dengan cara yang paling efektif, efisien, dan ekonomis; 3) Memimpin, yaitu pekerjaan seorang guru untuk memotivasikan, mendorong, dan menstimulasikan murid-muridnya, sehingga mereka siap mewujudkan tujuan belajar; dan 4) Mengawasi, yaitu pekerjaan seorang guru untuk menentukan apakah fungsinya dalam mengorganisasikan dan memimpin di atas telah berhasil dalam mewujudkan tujuan yang telah dirumuskan. Jika tujuan belum dapat diwujudkan, maka guru harus menilai dan mengatur kembali.

Per-Menpan No. 16 Tahun 2009 tentang jabatan fungsional guru, bahwa tugas pokok utama yang harus dimiliki oleh guru terbagi tiga, yaitu perencanaan pembelajaran, pelaksanaan kegiatan pembelajaran,dan penilaianatau evaluasi pembelajaran. Adapun penjelasan dari ketiga tugas pokok tersebut yaitu:

a. Perencanaan Pembelajaran

Sebelum melaksanakan kegiatan pembelajaran, seorang guru dituntut membuat perencanaan pembelajaran, fungsi perencanaan pembelajaran ialah 
untuk mempermudah guru dalam melaksanakan tugas selanjutnya. Sehingga proses belajar mengajar akan benar-benar tersusun dengan baik, efektif dan efisien. Per-Menpan No. 16 Tahun 2009 tentang jabatan fungsional guru, menjelaskan bahwa dalam praktik pengajaran di sekolah, terdapat beberapa aspek perencanaan pembelajaran, yaitu :

1. Guru memformulasikan tujuan pembelajaran dalam Rencana Pelaksanaan Pembelajaran (RPP) sesuai dengan kurikulum/silabus dan memperhatikan karakteristik peserta didik. Dalam aspek ini terdiri dari tiga indikator yakni: a) Tujuan pembelajaran dirumuskan dan dikembangkan berdasarkan SK/KD yang akan dicapai; b) Tujuan pembelajaran memuat gambaran proses dan hasil belajar yang dapat dicapai oleh peserta didik sesuai dengan kebutuhan belajarnya; dan c) Tujuan pembelajaran disesuaikan dengan kebutuhan belajar peserta didik.

2. Guru menyusun bahan ajar secara runut, logis, kontekstual dan mutakhir. Dalam aspek ini terdiri dari empat indikator yakni: a) Bahan ajar disusun dari yang sederhana ke kompleks sesuai dengan tujuan pembelajaran; b) Keluasan dan kedalaman bahan ajar disusun dengan memperhatikan potensi peserta didik (termasuk yang cepat dan lambat, motivasi tinggi dan rendah); c) Bahan ajar dirancang sesuai dengan konteks kehidupan dan perkembangan IPTEK; dan d) Bahan ajar dirancang sesuai dengan menggunakan sumber yang bervariasi (tidak hanya buku pegangan peserta didik).

3. Guru merencanakan kegiatan pembelajaran yang efektif. Dalam aspek ini terdiri dari empat indikator yakni: a) Strategi, pendekatan, dan metode pembelajaran relevan untuk mencapai tujuan pembelajaran yang ingin dicapai/kompetensi harus dikuasai peserta didik; b) Strategi dan metode pembelajaran yang dipilih dapat memudahkan pemahaman peserta didik; c) Strategi dan metode pembelajaran yang dipilih sesuai dengan tingkat perkembangan kognitif, afektif, dan psikomotorik peserta didik; dan d) Setiap tahapan pembelajaran diberi alokasi waktu secara proporsional dengan memperhatikan tingkat kompleksitas materi dan/atau kebutuhan peserta didik.

4. Guru memilih sumber belajar/media pembelajaran sesuai dengan materi dan strategi pembelajaran. Dalam aspek ini terdapat tiga indikator yakni: a) Sumber belajar/media pembelajaran yang dipilih dapat dipakai untuk mencapai tujuan pembelajaran misalnya buku, modul untuk kompetensi kognitif, media audio visual, komputer untuk kompetensi keterampilan; b) Sumber belajar/media pembelajaran termasuk TIK yang dipilih dapat memudahkan pemahaman peserta didik; dan c) Sumber belajar/media pembelajaran yang dipilih sesuai dengan tingkat perkembangan kognitif, afektif dan psikomotorik peserta didik.

b. Pelaksanaan kegiatan pembelajaran

Setelah melakukan kegiatan perencanaan pembelajaran langkah selanjutnya yang dilakukan oleh guru adalah pelaksanaan kegiatan pembelajaran yang merupakan aktivitas inti disekolah. Basyiruddin Usman (Asf \&Mustofa,2013:173) menyebutkan bahwa mengajar adalah suatu usaha bagaimana mengatur lingkungan dan adanya interaksi subjek didik (anak) dengan lingkungannya sehingga tercipta kondisi belajar yang baik. Menurut User Usman (Asf \&Mustofa,2013:175) dalam melakukan proses pembelajaran tentunya harus dipersiapkan berbagai hal sehingga proses pembelajaran mempunyai makna, terarah, dan tercapai tujuan. Hal-hal yang harus 
diperhatikan sebelum melaksanakan proses belajar-mengajar adalah (1) merumuskan tujuan yang hendak dicapai, (2) menentukan materi pembelajaran yang sesuai dengan tujuan, (3) menentukan metode yang tepat sesuai dengan materi yang hendak disampaikan, (4) menentukan alat peraga yang cocok dengan penyampaian materi, dan (5) menentukan alat evaluasi yang dapat mengukur tercapai atau tidaknya materi yang telah disampaikan. Dengan demikian belajar-mengajar merupakan suatu sistem yang terdiri dari berbagai komponen yang saling berkaitan satu sama lain dan merupakan satu kesatuan yang tak terpisahkan. Selain peran dan tugas guru dalam melakukan hal-hal tersebut diatas, juga tugas guru yang paling utama dalam proses pelaksanaan belajar-mengajar adalah (1) sebagai demonstrator, (2) sebagai pengelola kelas, (3) sebagai moderator dan fasilitator, dan (4) sebagai evaluator. Per-MenpanNo. 16 Tahun 2009 tentang jabatan fungsional guru, menjelaskan bahwa pelaksanaan kegiatan pembelajaran terdiri dari beberapa aspek yaitu:

1. Dalam kegiatan pendahuluan, guru memulai pembelajaran dengan efektif. Terdiri dari dua indikator yakni: a) Melakukan apersepsi; dan b) Menyampaikan kompetensi yang akan dicapai dalam rencana kegiatan.

2. Dalam kegiatan inti, terdiri dari:

a. Guru harus menguasai materi pembelajaran. Terdiri dari empat indikator yakni: a) Kemampuan menyesuaikan materi dengan tujuan pembelajaran; b) Kemampuan mengaitkan materi dengan pengetahuan lain yang relevan, perkembangan IPTEK dan kehidupan nyata; c) Tingkat ketepatan pembahasan dengan materi pembelajaran; dan d) Kemampuan menyajikan materi secara sistematis (mudah ke sulit, dari konkrit ke abstrak)

b. Guru menerapkan pendekatan/strategi pembelajaran yang efektif. Terdiri dari enam indikator yakni: a) Melaksanakan pembelajaran sesuai dengan kompetensi yang akan dicapai; b) Melaksanakan pembelajaran secara runtut; c) Menguasai kelas; d) Melaksanakan pembelajaran yang bersifat kontekstual; e) Melaksanakan pembelajaran yang memungkinkan tumbuhnya kebiasaan positif; dan f) Melaksanakan pembelajaran sesuai dengan alokasi waktu yang direncanakan.

c. Guru memanfaatkan sumber belajar/media dalam pembelajaran. Terdiri dari tiga indikator yakni: a) Menunjukan keterampilan dalam penggunaan media pembelajaran; b) Menghasilkan pesan yang menarik; dan c) Melibatkan siswa dalam pembuatan dan pemanfaatan sumber belajar/media pembelajaran.

d. Guru memicu dan/atau memelihara keterlibatan siswa dalam pembelajaran. Terdiri dari lima indikator yakni: a) Menumbuhkan partisipasi aktif siswa melalui interaksi guru, siswa, sumber belajar; b) Merespon positif partisipasi siswa; c) Menunjukan sikap terbuka terhadap respon siswa; d) Menunjukan hubungan antar pribadi yang kondusif; dan e) Menumbuhkan keceriaan dan antusisme siswa dalam belajar

e. Guru menggunakan bahasa yang benar dan tepat dalam pembelajaran. Terdiri dari tiga indikator yakni: a) Menggunakan bahasa lisan secara jelas dan lancar; b) Menggunakan bahasa tulis yang baik dan benar; dan c) Menyampaikan pesan dengan gaya yang sesuai. 
3. Dalam kegiatan penutup, guru mengakhiri pembelajaran dengan efektif. Terdiri dari dua indikator yakni: a) Melakukan refleksi atau membuat rangkuman dengan melibatkan siswa; dan b) Melaksanakan tindak lanjut dengan memberikan arahan, atau kegiatan atau tugas sebagai pengayaan .

c. Penilaian atau evaluasi pembelajaran

Kegiatan penilaian pembelajaran merupakan bagian terpenting dalam pembelajaran, yang dilakukan oleh seorang guru untuk mengetahui tingkat pengetahuan awal, kecakapan siswa dan program pengajaran. Evaluasi dapat dilakukan awal pelajaran untuk mengetahui sejauhmana tingkat pengetahuan awal siswa, dan uji akhir dari proses pembelajaran, yaitu untuk mendapat gambaran kecakapan, penyerapan dari suatu penyajian yang telah dilaksanakan pada akhir pelajaran. Hamalik (1995:159) mengemukakan bahwa evaluasi merupakan keseluruhan kegiatan pengukuran (pengumpulan data dan informasi), pengolahan, penafsiran dan pertimbangan untuk membuat keputusan tentang tingkat hasil belajar yang dicapai peserta didik setelah melakukan kegiatan belajar dalam upaya mencapai tujuan pembelajaran yang telah ditetapkan. Evaluasi yang dilakukan berguna untuk melihat perubahan kecakapan dalam tingkat pengetahuan, kemahiran dalam keterampilan, serta perubahan sikap dalam satu unit pembelajaran atau dalam program kegiatan pembelajaran yang telah dilakukan. Guru melakukan penilaian berdasarkan pada indikator yang dikembangkan dari kemampuan dasar sesuai materi pelajaran yang telah diajarkan (Yamin, 2013:179).

Per-Menpan No.16 Tahun 2009 tentang jabatan fungsional guru, menjelaskan bahwa penilaian atau evaluasi pembelajaran terdiri dari beberapa aspek yaitu :

1. Guru merancang alat evaluasi untuk mengukur kemajuan dan keberhasilan belajar peserta didik. Terdiri empat indikator yakni: a) Kesesuaian teknik dan jenis penilaian (tes lisan, tertulis, tes pembuatan) sesuai dengan tujuan pembelajaran; b) Alat tes dirancang untuk dapat mengukur kemajuan belajar peserta didik dari aspek kognitif, afektif dan psikomotorik; c) Rancangan penilaian portofolio peserta didik minimal satu kali persemester; dan d) Hasil analisis penilaian sebelumnya (UH, UAS) digunakan untuk keperluan program perbaikan (remedial, pengayaan dan menyempurnakan rancangan pelaksanaan pembelajaran.

2. Guru menggunakan berbagai strategi dan metode penilaian untuk memantau kemajuan dan hasil belajar peserta didik dalam mencapai kompetensi tertentu sebagaimana yang tertulis dalam Rencana Pelaksanaan Pembelajaran. Terdiri dari empat indikator yakni: a) Menggunakan teknik penilaian otentik (kuis, pertanyaan lisan, pemberian tugas) untuk memantau kemajuan belajar peserta didik; b) Menggunakan teknik penilaian (UH,UAS) disusun untuk mengukur hasil belajar peserta didik dalam aspek kognitif, afektif dan psikomotorik; c) Menerapkan penilaian portofolio dalam bentuk berbagai tugas terstruktur; dan d) Menggunakan alat penilaian yang sesuai dengan tujuan pembelajaran dan materi ajar sebagaimana disusun dalam rencana pelaksanaan pembelajaran.

3. Guru memanfaatkan berbagai hasil penilaian untuk memberi umpan balik bagi peserta didik tentang kemajuan belajarnya dan bahan penyusunan rancangan pembelajaran selanjutnya. Terdiri dari empat indikator yakni: a) Menggunakan hasil analisis penilaian untuk mengidentifikasi topik/kompetensi dasar yang mudah, sedang dan sulit sehingga diketahui kekuatan dan kelemahan masing- 
masing peserta didik untuk keperluan remedial dan pengayaan; b) Menggunakan hasil penilaian untuk menyempurnakan rancangan pelaksanaan pembelajaran; c) Melaporkan kemajuan dan hasil belajar peserta didik kepada orang tua, teman guru dan bagi peserta didik sebagai refleksi belajarnya; dan d) Memanfaatkan hasil penilaian secara efektif untuk mengidentifikasi kekuatan, kelemahan, tantangan dan masalah potensial untuk peningkatan keprofesian dalam menunjang proses pembelajaran.

Faktor-faktor yang mempengaruhi kinerja guru juga dapat digolongkan ke dalam dua macam yaitu:

a. Faktor dari dalam sendiri (intern)

Di antara faktor dari dalam diri sendiri (intern) adalah: a) Kemampuan (ability), Syarat untuk mendapatkan ketenangan kerja bagi seseorang adalah tugas dan jabatan yang sesuai dengan kemampuannya. Kemampuan yang disertai dengan minat yang tinggi dapat menunjang pekerjaan yang telah ditekun; b) Motivasi (motivation), Motivasi adalah dorongan atau kehendak dari dalam diri seseorang untuk melaksanakan tindakan atau kegiatan dalam lingkup tugas-tugas yang merupakan pekerjaan dilingkungan sebuah organisasi. Menurut Gray (J. Winardi, 2002:2) mengatakan bahwa motivasi merupakan suatu proses yang bersifat internal yang menyebabkan timbulnya sikap antusiasme seseorang dalam melaksanakan suatu kegiatan tertentu. Seseorang yang melakukan tindakan atau bekerja tentu karena didorong oleh kebutuhan yang dapat dipenuhi melalui kinerjanya. Semakin besar tuntunan atau harapan akan terpenuhinya kebutuhan, semakin besar pula dorongan untuk bekerja. Motivasi kerja yang kuat dan permanen dapat berkembang menjadi motivasi berprestasi; c) Tingkat pendidikan guru, Tingkat pendidikan guru dapat mempengarahi baik tidaknya kinerja guru. Kemampuan seseorang sangat dipengaruhi oleh tingkat pendidikannya, karena melalui pendidikan itulah seorang mengalami pola pikir yang baik, sehingga kinerjanya baik pula; dan d) Kondisi fisik (Kesehatan), Kesehatan dapat membantu proses bekerja seseorang sampai selesai. Jika kesehatan terganggu maka pekerjaan terganggu pula.

b. Faktor dari luar diri sendiri (ekstern)

Yang termasuk faktor dari luar diri sendiri (ekstern) adalah: a) Iklim Sekolah, Situasi kerja yang menyenangkan dapat mendorong seseorang bekerja secara optimal. Tidak jarang kekecewaan dan kegagalan dialami seseorang di tempat ia bekerja. Lingkungan kerja yang dimaksud di sini adalah situasi kerja, rasa aman, gaji yang memadai, kesempatan untuk mengembangkan karir, dan rekan kerja; b) Kepemimpinan kepala sekolah, Komunikasi yang baik di sekolah adalah komunikasi yang efektif. Tidak adanya komunikasi yang efektif dapat mengakibatkan timbulnya salah pengertian; dan d) Sarana dan prasarana, Adanya sarana dan prasarana yang memadai membantu guru dalam meningkatkan kinerjanya terutama kinerja dalam proses mengajar.

\section{METODE PENELITIAN}

Penelitian ini bersifat deskriptif kualitatif. Responden dalam penelitian ini adalah seluruh guru mata pelajaran PKn yang berjumlah 3 orang yang sudah bersertifikat. Informan dalam penelitian ini adalah adalah berjumlah 3 orang yakni Kepala Sekolah SMK Negeri 4 Kendari, Wakil Kepala Sekolah bagian Kurikulum 
dan Pengawas Sekolah Menengah Kejuruan Negeri. Teknik Pengumpulan Data yaitu: 1) penelitian kepustakaan (library research); 2) penelitian lapangan (field research), yaitu mengumpulkan data dan informasi secara langsung di lapangan dengan teknik; a) wawancara; b) dokumentasi. Teknik analisis data yakni kualitatif, meliputi: Data Reduction (Reduksi Data); Data display (Penyajian Data); Conclution drawing/verivication (Penarikan Kesimpulan).

\section{HASIL PENELITIAN DAN PEMBAHASAN}

A. Kinerja Guru PKn yang Memiliki Sertifikat Pendidik SMK Negeri 4 Kendari

1) Perencanaan Pembelajaran

Perencanaan pembelajaran adalah rencana yang dibuat oleh guru untuk memproyeksikan kegiatan apa yang akan dilakukan oleh guru dan siswa agar tujuan pembelajaran dapat tercapai. Oleh karena itu Sebelum melasanakan proses belajar mengajar guru harus mempersiapkan perencanaan pembelajaran agar dalam proses belajar mengajar tersusun secara sistematis. Sesuai dengan PerMenpan Nomor 16 tahun 2009, dalam perencanaan pembelajaran, ada beberapa hal yang harus dilakukan oleh guru. Untuk lebih jelasnya dapat dilihat pada tabel hasil penelitan terhadap guru PKn SMK Negeri 4 Kendari dibawah ini, sebagai berikut :

a. Memformulasikan Tujuan Pembelajaran dalam Rencana Pelaksanaan Pembelajaran (RPP) sesuai dengan Kurikulum/Silabus dan Memperhatikan Karakteristik Peserta Didik

Tujuan dalam proses belajar mengajar merupakan komponen pertama yang harus ditetapkan dalam proses pengajaran yang berfungsi sebagai indikator keberhasilan pengajaran. Tujuan ini pada dasarnya adalah rumusan tingkah laku dan kemampuan yang harus dicapai dan dimiliki siswa setelah mereka menyelesaikan kegiatan belajar dalam proses pengajaran. Oleh karena itu sesuai dengan PerMenpan No. 16 tahun 2009, seorang guru harus memformulasikan tujuan pembelajaran dalam RPP sesuai dengan kurikulum dan memperhatikan karakter peserta didik. Dalam memformulasikan tujuan pembelajaran dalam RPP sesuai dengan kurikulum/silabus dan memperhatikan karakteristik peserta didik, semua guru PKn SMK Negeri 4 Kendari dapat mengikuti semua indikator penilaian secara baik yang telah ditetapkan pada aspek ini, yakni pada poin 1 semua guru PKn SMK Negeri 4 Kendaridalam membuat perencanaan pembelajaran yang pertama dilakukannya adalah tujuan pembelajaran dirumuskan dan dikembangkan berdasarkan SK/KD yang akan dicapai secara baik. Selanjutnya pada poin 2 yakni tujuan pembelajaran memuat gambaran proses dan hasil belajar yang dapat dicapai oleh peserta didik sesuai dengan kebutuhan belajarnya, guru PKn juga telah membuatnya secara baik, sehingga siswa sangat bersemangat dalam menerima pelajaran. Pada poin 3 yakni tujuan pembelajaran disesuaikan dengan kebutuhan belajar peserta didik, guru PKn juga telah membuatnya secara baik, sehingga siswa juga sangat semangat dalam menerima pelajaran.

b. Menyusun Bahan Ajar Secara Runut, Logis, Kontekstual Dan Mutakhir

Bahan ajar merupakan seperangkat materi/substansi pembelajaran 
(teaching material) yang disusun secara sistematis, menampilkan sosok utuh dari kompetensi yang akan dikuasai siswa dalam kegiatan pembelajaran. Dengan bahan ajar memungkinkan siswa dapat mempelajari suatu kompetensi atau KD secara runtut dan sistematis sehingga secara akumulatif mampu menguasai semua kompetensi secara utuh dan terpadu. Bahan ajar juga merupakan informasi, alat dan teks yang diperlukan guru/instruktor untuk perencanaan dan penelaahan implementasi pembelajaran, bahan yang dimaksud bisa berupa bahan tertulis maupun bahan tidak tertulis. Dalam menyusun bahan ajar secara runut, logis, kontekstual dan mutakhir semua guru PKn SMK Negeri 4 Kendari dapat mengikuti semua indikator penilaian yang telah ditetapkan dengan baik, yaitu pada poin 1 yakni bahan ajar disusun dari yang sederhana kekompleks sesuai dengan tujuan pembelajaran. Poin 2 keluasan dan kedalaman bahan ajar disusun dengan memperhatikan potensi peserta didik (termasuk yang cepat dan lambat, motivasi tinggi dan rendah).Poin 3 bahan ajar dirancang sesuai dengan konteks kehidupan dan perkembangan IPTEK, dan terakhir ke-4 bahan ajar dirancang sesuai dengan menggunakan sumber yang bervariasi (tidak hanya buku pegangan peserta didik).

\section{c. Merencanakan Kegiatan Pembelajaran yang Efektif}

Pembelajaran yang efektif adalah proses belajar mengajar yang bukan saja terfokus kepada hasil yang dicapai peserta didik, namun bagaimana proses pembelajaran yang efektif mampu memberikan pemahaman yang baik, kecerdasan, ketekunan, kesempatan dan mutu serta dapat memberikan perubahan perilaku dan mengaplikasikannya dalam kehidupan mereka. Pembelajaran efektif juga dapat menciptakan suasana pembelajaran yang menyenangkan sehingga memberikan kreatifitas siswa untuk mampu belajar dengan potensi yang sudah mereka miliki yaitu dengan memberikan kebebasan dalam melaksanakan pembelajaran dengan cara belajarnya sendiri. Dalam menempuh dan mewujudkan tujuan pembelajaran yang efektif maka perlu dilakukan sebuah cara agar proses pembelajaran yang diinginkan tercapai yaitu dengan cara belajar efektif. Dalam perencanaan pembelajaran yaitu merencanakan kegiatan pembelajaran yang efektif, semua guru PKn telah mengikuti 4 poin indikator penilaian tersebut, yaitu pada poin 1 dalam merencanakan pembelajaran yang efektif guru membuat strategi, pendekatan, dan metode pembelajaran relevan untuk mencapai tujuan pembelajaran yang ingin dicapai/kompetensi harus dikuasai peserta didik.Selanjutnya pada poin 2 strategi dan metode pembelajaran yang dipilih memudahkan pemahaman peserta didik. Pada poin 3 strategi dan metode pembelajaran yang dipilih sesuai dengan tingkat perkembangan kognitif, efektif, dan psikomotor peserta didik, dan pada poin 4 setiap tahapan pembelajaran diberi alokasi waktu secara proporsional dengan memperhatikan tingkat kompleksitas materi dan/atau kebutuhan belajar peserta didik.

\section{d. Memilih Sumber Belajar/Media Pembelajaran sesuai dengan Materi} dan Strategi Pembelajaran

Media dan sumber belajar merupakan faktor yang harus dipertimbangkan dalam merencanakan pembelajaran. Media dan sumber 
belajar yang dipilih harus sesuai dengan kegiatan. Pemilihan media dan sumber belajar harus mempertimbangkan karakteristik perkembangan dan karakteristik peserta didik. Materi pembelajaran merupakan unsur belajar yang penting mendapat perhatian oleh guru. Materi pelajaran merupakan medium untuk mencapai tujuan pembelajaran yang "dikonsumsi" oleh siswa. Karena itu, penentuan materi pelajaran mesti berdasarkan tujuan yang hendak dicapai.Sedangkan strategi pembelajaran merupakan suatu kegiatan pembelajaran yang harus dikerjakan oleh guru dan siswa agar tujuan pembelajaran dapat dicapai secara efektif dan efisien. Dalam perencanaan pembelajaran semua guru PKn SMK Negeri 4 Kendari dapat mengikuti semua indikator penilaian yang telah ditetapkan pada aspek memilih sumber belajar/media pembelajaran sesuai dengan materi dan strategi pembelajaran dengan baik, yaitu pada poin 1 sumber belajar yang dibuat oleh semua guru PKn dapat dipakai untuk mencapai tujuan pembelajaran. Selanjutnya pada poin 2 sumber belajar atau media pembelajaran yang dipakai oleh semua guru PKn dapat memudahkan pemahaman peserta didik.Serta poin 3 sumber belajar/media pembelajaran yang dipilih oleh semua guru PKn sesuai dengan tingkat perkembangan kognitif, afektif dan psikomotorik peserta didik.

Selanjutnya untuk menghitung atau menilai kinerja guru Pendidikan Pancasila dan Kewarganegaraan (PKn) yang memiliki sertifikat pendidik SMK Negeri 4 Kendari dalam perencanaan pembelajaran, penelitian ini menggunakan mekanisme perhitungan atau penilaian yang ditetapkan oleh PerMenpan No. 16 Tahun 2009, sebagai berikut :

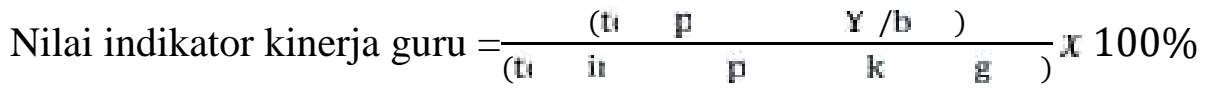

Keterangan :

$(0<\mathrm{x} \measuredangle 25 \%)=1$ (kurang baik)

$(25 \%<\mathrm{x} 50 \%)=2$ (cukup baik)

$(50<\mathrm{x} \leq 75 \%)=3$ (baik)

$(75 \%<x \leq 100 \%)=4$ (sangat baik)

Berdasarkan hasil penelitian dan pembahasan maka dapat diuraikan berdasarkan rumus sebagai berikut :

a. Memformulasikan Tujuan Pembelajaran dalam Rencana Pelaksanaan Pembelajaran (RPP) sesuai dengan Kurikulum/Silabus dan Memperhatikan Karakteristik Peserta Didik

Guru $\mathrm{I}=3 / 3 \times 100 \%=100 \%$ berdasarkan keterangan rumus maka untuk guru I memperoleh nilai 4 (sangat baik)

$>$ Guru II $=3 / 3 \times 100 \%=100 \%$ berdasarkan keterangan rumus maka untuk guru II memperoleh nilai 4 (sangat baik)

$>$ Guru III $=3 / 3 \times 100 \%=100 \%$ berdasarkan keterangan rumus maka untuk guru III memperoleh nilai 4 (sangat baik)

b. Menyusun Bahan Ajar Secara Runut, Logis, Kontekstual Dan Mutakhir

Guru I $=4 / 4 \times 100 \%=100 \%$ berdasarkan keterangan rumus maka untuk guru I memperoleh nilai 4 (sangat baik) 
$>$ Guru II $=4 / 4 \times 100 \%=100 \%$ berdasarkan keterangan rumus maka untuk guru II memperoleh nilai 4 (sangat baik)

$>$ Guru III $=4 / 4 \times 100 \%=100 \%$ berdasarkan keterangan rumus maka untuk guru III memperoleh nilai 4 (sangat baik)

c. Merencanakan Kegiatan Pembelajaran yang Efektif

$>$ Guru $\mathrm{I}=4 / 4 \times 100 \%=100 \%$ berdasarkan keterangan rumus maka untuk guru I memperoleh nilai 4 (sangat baik)

$>$ Guru II $=4 / 4 \times 100 \%=100 \%$ berdasarkan keterangan rumus maka untuk guru II memperoleh nilai 4 (sangat baik)

$>$ Guru III $=4 / 4 \times 100 \%=100 \%$ berdasarkan keterangan rumus maka untuk guru III memperoleh nilai 4 (sangat baik)

d. Memilih Sumber Belajar/Media Pembelajaran sesuai dengan Materi dan Strategi Pembelajaran

Guru $\mathrm{I}=3 / 3 \times 100 \%=100 \%$ berdasarkan keterangan rumus maka untuk guru I memperoleh nilai 4 (sangat baik)

$>$ Guru II $=3 / 3 \times 100 \%=100 \%$ berdasarkan keterangan rumus maka untuk guru II memperoleh nilai 4 (sangat baik)

$>$ Guru III $=3 / 3 \times 100 \%=100 \%$ berdasarkan keterangan rumus maka untuk guru III memperoleh nilai 4 (sangat baik).

Berdasarkan hasil perhitungan dengan menggunakan rumus PerMenpan No.16 tahun 2009 maka dapat diketahui bahwa tiga orang guru Pendidikan Pancasila dan Kewarganegaraan (PKn) yang telah bersertifikat SMK Negeri 4 Kendari dalam perencanaan pembelajaran memperoleh skor 4 (sangat baik).

\section{2) Pelaksanaan Kegiatan Pembelajaran}

Pelaksanaan pembelajaran dilakukan dalam bentuk interaksi antara guru dengan siswa pada saat melakukan proses belajar mengajar. Interaksi yang dimaksudnya adalah interaksi dalam pelaksanaan pembelajaran. Dalam melaksanakan kegiatan pembelajaran, seorang guru harus memahami langkah-langkah yang akan ditempuh. Adapun langkah-langkah yang harus ditempuh dalam pelaksanaan pembelajaran sesuai dengan PerMenpan No. 16 tahun 2009 meliputi: kegiatan pendahuluan, kegiatan inti pembelajaran dan kegiatan akhir/penutup. Untuk lebih jelasnya dapat diuraikan sebagai berikut :

\section{Kegiatan Pendahuluan}

Kegiatan pendahuluan adalah awal atau pertama yang dilakukan guru dalam pelaksanaan pembelajaran yang akan dilangsungkan. Salah satu hal yang harus dilakukan oleh semua guru PKn SMK Negeri 4 Kendari pada kegiatan pendahuluan dalam pelaksanaan pembelajaran adalah Memulai Pembelajaran dengan Efektif.Pembelajaran afektif yang dimaksud adalah pembelajaran yang mencapai sasaran yang diinginkan dalam pembelajaran tersebut, sehingga para siswa dapat mengetahui dan memahami maksud dan tujuan pembelajaran. Dalam pelaksanaan kegiatan pembelajaran dari semua tiga orang guru PKn SMK Negeri 4 Kendari pada 
kegiatan pendahuluan, hanya satu orang guru yang melakukan apersepsi dengan baik yakni guru pertama, di mana dalam kegiatan apersepsi ini guru PKn SMK Negeri 4 Kendari mengajak peserta didik agar mengulangi pelajaran yang telah dipelajari sebelumnya. Selain itu juga mengajak siswa untuk mengingat kembali materi pelajaran yang telah diajarkan sebelumnya. Sedangkan guru kedua dalam melakukan kegiatan apersepsi kurang baik, dimana guru tidak mengajak peserta didik untuk mengingat kembali yang telah dipelajari sebelumnya dan guru ketiga sama sekali tidak melakukan kegiatan apersepsi sebelum melaksanakan proses kegiatan pembelajaran.Sedangkan pada poin 2 semua guru PKn dapat menyampaikan kompetensi yang akan dicapai dalam rencana kegiatan pembelajaran dengan baik.

2. Kegiatan Inti

a. Menguasai Materi Pelajaran Pendidikan Kewarganegaraan

Salah satu faktor utama yang penting yang harus diperhatikan oleh guru pada saat melaksanakan proses belajar mengajar adalah harus menguasai materi pelajaran yang akan diajarkan kepada siswa (student). Hal itu dikarenakan dalam proses belajar mengajar berlangsung adanya hubungan interaksi antara guru dan siswa yang berkaitan dengan materi yang diajarkan. Sungguh sangat menyedihkan jika seorang guru tidak mampu menguasai materi pelajaran yang akan diajarkan kepada siswanya.

Sebagai seorang guru, haruslah mempersiapkan diri sebelum akan melaksanakan kegiatan pembelajaran. Karena guru merupakan pribadi yang memiliki kemampuan yakni ilmu pengetahuan mengajar.Dengan kemampuan tersebut, guru dapat mentransferkan ilmu kepada siswanya, sehingga mereka dapat memperoleh pengetahuan yang luas. Dalam kegiatan inti pembelajaran pada penguasaan materi pelajaran, hanya satu orang guru yang dapat mengikuti semua indikator penilaian dalam aspek ini yakni guru kedua. Sedangkan guru satu dan guru tiga belum dapat mengikuti semua indikator penilaian dengan baik.Pada poin 1 dan 3 semua guru PKn dapat menyesuaikan materi pelajaran dengan tujuan pembelajaran dan mampu menjelaskan secara tepat sesuai materi pembelajaran yang diajarkan dengan baik. Sedangkan pada poin 2 dan 4 guru satu dan guru tiga kurang baik dalam mengaitkan materi dengan pengetahuan lain yang relevan, yakni mereka hanya mengaitkan materi pelajaran dengan kehidupan nyata tanpa mengaitkan dengan perkembangan IPTEK dan dalam menyajikan materi pelajaran tidak secara sistematis yakni dalam menjelaskan materi pelajaran tidak berdasarkan susunan materi yang tertulis dalam rencana pelaksanaan pembelajaran.

\section{b. Menerapkan Pendekatan/Strategi Pembelajaran yang Efektif}

Pendekatan pembelajaran diartikan sebagai sudut pandang atau titik tolak terhadap proses pembelajaran. Sedangkan strategi pembelajaran merupakan suatu kegiatan pembelajaran yang harus dikerjakan oleh guru dan siswa agar tujuan pembelajaran dapat dicapai secara efektif dan efesien. Strategi pembelajaran mengandung makna perencanaan, yang artinya strategi pada dasarnya masih bersifat konseptual tentang keputusankeputusan yang akan diambil dalam pelaksanaan pembelajaran. Dalam pendekatan atau strategi pembelajaran efektif, yang terdiri dari 6 poin 
indikator semua guru PKn belum dapat mengikuti semua indikator penilaian secara sempurna. Dapat dilihat pada poin3 semua guru PKn tidak dapat menguasai kelas sehingga membuat siswa keluar masuk dan tidak memperhatikan materi pelajaran.Sedangkan dalam indikator yang lain hanya satu orang guru yang belum dapat melaksanakan secara baik, yakni pada indikator poin 6 oleh guru dua, belum dapat melaksanakan pembelajaran sesuai dengan alokasi waktu yang telah ditetapkan.

c. Memanfaatkan Sumber Belajar/Media Dalam Pembelajaran

Agar tujuan pendidikan bisa tercapai, maka perlu diperhatikan segala sesuatu yang mendukung keberhasilan program pendidikan itu. Untuk itu perlu sekali dalam proses pembelajaran diciptakan suasana yang kondusif, agar peserta didik benar-benar tertarik dan ikut aktif dalam proses tersebut. Dalam kaitannya dengan usaha menciptakan suasana yang kondusif, media merupakan salah satu faktor yang turut menentukan keberhasilan pembelajaran.

Istilah media berasal dari bahasa latin yaitu medium yang secara harfiah berarti tengah, perantara atau pengantar artinya segala sesuatu yang dapat menyalurkan pesan atau informasi dari pengirim kepada penerima pesan. Dalam aktivitas pembelajaran, media diartikan sebagai sesuatu yang dapat membawa informasi dan pengetahuan dalam interaksi yang berlangsung antara pendidik dengan siswa.

Secara umum manfaat media pembelajaran adalah untuk memperlancar interaksi antara guru dengan peserta didik sehingga kegiatan pembelajaran lebih efektif dan efisien. Dari semua guru PKn di SMK Negeri 4 Kendari padapemanfaatan Sumber Belajar/Media Dalam Pembelajaran dengan 3 indikator penilaian yang telah ditetapkan pada aspekini hanya dua poin indikator yang dapat dilakukan oleh guru PKn yakni pada poin 1 dan poin 2, guru PKn dapat menggunakan media pembelajaran secara baik, yang relevan dengan materi pembelajaran, sehingga dalam pelaksanaan kegiatan pembelajaran guru PKn melaksanakan dengan baik dan dalam pelaksanaan pembelajaran yang dilakukan dapat menghasilkan pesan yang menarik dengan memanfaatkam sumber belajar yang telah disiapkan misalnya guru memerintahkan siswa untuk mengerjakan soal-soal pada buku yang sudah dipersiapkan oleh guru dan selanjutnya didiskusikan. Sedangkan pada poin 3 semua guru PKn tidak melibatkan siswa dalam pemanfaatan sumber atau media pembelajaran yang akan diajarkan.

\section{d. Memicu dan Memelihara Keterlibatan Siswa dalam Pembelajaran}

Salah satu tugas guru juga di dalam proses pelaksanaan kegiatan pembelajaran adalah memicu dan memelihara keterlibatan siswa dalam proses pembelajaran. Sehingga dalam pelaksanaan pembelajaran dapat berjalan dengan baik dan lancar sesuai dengan keinginan siswa. Keterlibatan siswa disini dimaksudkan bahwa dalam proses pembelajaran siswa bukan hanya sebagai penerima tetapi juga aktif didalam proses pembelajaran. Dari tiga orang guru PKn SMK Negeri 4 Kendari dapat mengikuti semua indikator penilaian pada pembelajaran yang memicu dan memelihara keterlibatan siswa dalam pembelajaran dengan sempurna, yaitu pada poin 1 dan 2 guru PKn dapat menumbuhkan dan merespon partisipasi 
aktif siswa dalam pembelajaran sehingga pelaksanaan pembelajaran berlangsung dapat terlaksana dengan baik. Selanjunya dan pada poin 3 guru PKn dapat menunjukan sikap terbuka terhadap respon siswa, sehingga tercipta hubungan yang harmonis dalam pembelajaran.Pada poin berikutnya guru PKn juga dapat menumbuhkan keceriaan dan antisiasme dalam belajar sehingga siswa sangat aktif dan serius dalam pembelajaran.

e. Menggunakan Bahasa yang Benar dan Tepat dalam Pembelajaran

Dalam proses pelaksanaan kegiatan pembelajaran bahasa yang benar dan tepat sangat penting yang harus diperhatikan oleh guru. Karena apabila seorang guru tidak memperhatikan bahasa yang diucapkan dalam proses pembelajaran akan menjadikan peserta didik sulit dalam menerima pelajaran yang diberikan oleh guru yang bersangkutan. Oleh sebab itu guru harus menggunakan bahasa yang mudah dipahami oleh peserta didik, Sehingga tujuan pembelajaran dapat tercapai dengan baik. Dari semua PKn SMK Negeri 4 Kendari telah mengikuti semua indikator penilaian pada aspek pembelajaran menggunakan bahasa yang benar dan tepat dengan baik, yaitu pada poin 1 guru PKn dapat menggunakan bahasa lisan secara jelas dan lancar dan pada poin ke-2 guru PKn dapat menggunakan bahasa tulis yang baik dan benar serta dapat menyampaikan pesan dengan gaya yang sesuai.

\section{Kegiatan Penutup}

Kegiatan penutup dalam pelaksanaan kegiatan pembelajaran adalah akhir dari pembelajaran yang dilakukan oleh guru dan siswa, dimana dalam kegiatan penutup ini guru ataupun siswa dapat mengajukan pertanyaan yang belum dipahami atau dimengerti, pertanyaan tersebut dapat dijawab oleh guru maupun siswa.Sesuai dengan PerMenpan No. 16 tahun 2009 dalam kegiatan penutup ini yang harus dilakukan oleh guru adalah mengakhiri pembelajaran dengan efektif. Dalam kegiatan penutup, semua guru PKn SMK Negeri 4 Kendari dari 2 poin indikator penilaian yang ditetapkan, hanya satu orang guru yang dapat mengikuti semua indikator penilaian yakni guru kedua. Sedangkan guru pertama dan guru ketiga hanya dapat mengikuti poin 2yakni melaksanakan tindak lanjut dengan memberi arahan atau kegiatan tugas sebagai bahan pengayaan kepada siswa untuk mengetahui sejauh mana siswa dalam memahami atau menguasai materi yang telah diberikan sebelumnya.Sedangkan pada poin 1 guru pertama dan guru kedua tidak melakukan refleksi atau membuat rangkuman dengan melibatkan siswa.

Selanjutnya untuk menghitung atau menilai kinerja guru Pendidikan Pancasila dan Kewarganegaraan (PKn) yang memiliki sertifikat pendidik SMK Negeri 4 Kendari dalam pelaksanaan kegiatan pembelajaran, penelitian ini menggunakan mekanisme perhitungan atau penilaian yang ditetapkan oleh PerMenpan No. 16 Tahun 2009, sebagai berikut : 


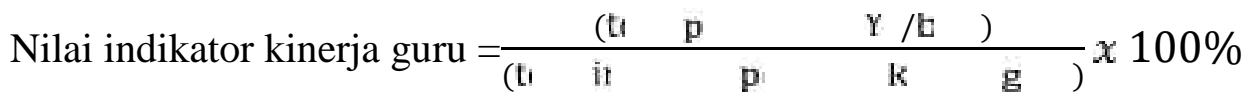

Keterangan :

$(0<\mathrm{x} \mathcal{2} 5 \%) \quad=1$ (kurang baik)

$(25 \%<\mathrm{x} 55 \%) \quad=2$ (cukup baik)

$(50<\mathrm{x} \leq 75 \%) \quad=3$ (baik)

$(75 \%<\mathrm{x} \leq 100 \%)=4$ (sangat baik)

Berdasarkan hasil penelitian dan pembahasan maka dapat diuraikan berdasarkan rumus sebagai berikut :

1. Kegiatan Pendahuluan

Memulai pembelajaran dengan efektif

$>$ Guru $\mathrm{I}=2 / 2 \times 100 \%=100 \%$ berdasarkan keterangan rumus maka untuk guru I memperoleh nilai 4 (sangat baik)

$>$ Guru II $=1 / 2 \times 100 \%=50 \%$ berdasarkan keterangan rumus maka untuk guru II memperoleh nilai 3 (baik)

$>$ Guru III $=1 / 2 \times 100 \%=50 \%$ berdasarkan keterangan rumus maka untuk guru III memperoleh nilai 3 (baik)

2. Kegiatan Inti

a. Menguasai Materi Pelajaran Pendidikan Kewarganegaraan

$>$ Guru $\mathrm{I}=2 / 4 \times 100 \%=50 \%$ berdasarkan keterangan rumus maka untuk guru I memperoleh nilai 3 (baik)

$>$ Guru II $=4 / 4 \times 100 \%=100 \%$ berdasarkan keterangan rumus maka untuk guru II memperoleh nilai 4 (sangat baik)

$>$ Guru III $=2 / 4 \times 100 \%=100 \%$ berdasarkan keterangan rumus maka untuk guru III memperoleh nilai 3 (baik)

b. Menerapkan Pendekatan/Strategi Pembelajaran yang Efektif

$>$ Guru $\mathrm{I}=5 / 6 \times 100 \%=80 \%$ berdasarkan keterangan rumus maka untuk guru I memperoleh nilai 4 (sangat baik)

$>$ Guru II $=4 / 6 \times 100 \%=60 \%$ berdasarkan keterangan rumus maka untuk guru II memperoleh nilai 3 (baik)

$>$ Guru III $=5 / 6 \times 100 \%=80 \%$ berdasarkan keterangan rumus maka untuk guru III memperoleh nilai 4 (sangat baik)

c. Memanfaatkan Sumber Belajar/Media Dalam Pembelajaran

$>$ Guru $\mathrm{I}=2 / 3 \times 100 \%=60 \%$ berdasarkan keterangan rumus maka untuk guru I memperoleh nilai 3 (baik)

$>$ Guru II $=2 / 3 \times 100 \%=60 \%$ berdasarkan keterangan rumus maka untuk guru II memperoleh nilai 3 (baik)

$>$ Guru III $=2 / 3 \times 100 \%=60 \%$ berdasarkan keterangan rumus maka untuk guru III memperoleh nilai 3 (baik)

d. Memicu dan Memelihara Keterlibatan Siswa dalam Pembelajaran

$>$ Guru $\mathrm{I}=3 / 3 \times 100 \%=100 \%$ berdasarkan keterangan rumus maka untuk guru I memperoleh nilai 4 (sangat baik)

$>$ Guru II $=3 / 3 \times 100 \%=100 \%$ berdasarkan keterangan rumus maka untuk guru II memperoleh nilai 4 (sangat baik)

$>$ Guru III $=3 / 3 \times 100 \%=100 \%$ berdasarkan keterangan rumus maka untuk guru III memperoleh nilai 4 (sangat baik)

e. MenggunakanBahasa yang Benar dan Tepat dalam Pembelajaran

$>$ Guru $\mathrm{I}=3 / 3 \times 100 \%=100 \%$ berdasarkan keterangan rumus maka 
untuk guru I memperoleh nilai 4 (sangat baik)

$>$ Guru II $=3 / 3 \times 100 \%=100 \%$ berdasarkan keterangan rumus maka untuk guru II memperoleh nilai 4 (sangat baik)

$>$ Guru III $=3 / 3 \times 100 \%=100 \%$ berdasarkan keterangan rumus maka untuk guru III memperoleh nilai 4 (sangat baik)

3. Kegiatan Penutup

Guru mengakhiri pembelajaran dengan efektif

$>$ Guru $\mathrm{I}=1 / 2 \times 100 \%=50 \%$ berdasarkan keterangan rumus maka untuk guru I memperoleh nilai 3 (baik)

$>$ Guru II $=2 / 2 \times 100 \%=100 \%$ berdasarkan keterangan rumus maka untuk guru II memperoleh nilai 4 (sangat baik)

$>$ Guru III $=1 / 2 \times 100 \%=50 \%$ berdasarkan keterangan rumus maka untuk guru I memperoleh nilai 3 (baik)

Berdasarkan hasil perhitungan dengan menggunakan rumus yang telah ditetapkan oleh PerMenpan No. 16 tahun 2009 maka dapat diketahui bahwa tiga orang guru Pendidikan Pancasila dan Kewarganegaraan (PKn) yang telah bersertifikat SMK Negeri 4 Kendari dalam pelaksanaan kegiatan pembelajaran, memperoleh skor 3 (baik). Dimana pada kegiatan pendahuluan memperoleh skor atau yang lebih banyak muncul adalah nilai 3 (baik), sedangkan dalam kegiatan inti pembelajaran memperoleh skor atau yang lebih banyak muncul adalah nilai 4 (sangat baik), serta dalam kegiatan penutup memperoleh skor atau yang lebih banyak muncul adalah nilai3 (baik).

\section{3). Penilaian Pembelajaran}

Penilaian diartikan sebagai proses dalam menentukan nilai suatu obyek, untuk dapat menentukan suatu nilai terhadap suatu obyek maka diperlukan adanya ukuran atau kriteria tertentu. Proses pemberian nilai tersebut berlangsung dalam bentuk interprestasi yang diakhiri dengan judgement yang merupakan tema penilaian yang mengimplikasikan adanya suatu perbandingan antara kriteria dan kenyataan dalam konteks situasi tertentu. Sesuai PerMenpan Nomor 16 tahun 2009 dalam kegiatan penilaian pembelajaran ini, ada beberapa hal yang harus dilakukan oleh guru, sebagai berikut:

a. Merancang Alat Evaluasi untuk Mengukur Kemajuan dan Keberhasilan Belajar Peserta Didik

Alat evaluasi merupakan alat untuk melihat perubahan kemampuan dan tingkah laku siswa setelah ia menerima materi pelajaran. Alat evaluasi yang salah, akan menggambarkan kemampuan dan tingkah laku yang salah pula. Oleh karena itu seorang guru harus mengikuti langkah-kangkah dalam penyusunan alat evaluasi.Sedangkan keberhasilan siswa disini adalah dilihat dari tiga aspek yakni bidang kognitif, afektif dan psikomotorik. Dalam penilaian atau evaluasi pembelajaran semua tiga orang guru PKn SMK Negeri 4 Kendari tidak dapat mengikuti semua indikator penilaian yang telah ditetapkan pada aspek merancang alat evaluasi untuk mengukur kemajuan dan keberhasilan belajar peserta didik, yaitu pada poin 1semua tiga orang guru PKn dapat menyesuaiakan tehnik 
dan jenis penilaian sesuai dengan tujuan pembelajaran. Selanjutnya pada poin 2 semua tiga orang guru PKn kurang baik dalam membuat alat test sesuai indicator penilaian yang ditetapkan, yakni semua tiga orang guru PKn, dalam membuat alat tes hanya mengukur aspek kognitif.Pada poin ke-3 hanya dua orang guru PKn yaitu guru pertama dan guru kedua yang membuat rancangan penilaian portofolio peserta didik 1 kali persemester sedangkan guru ketiga tidak membuat rancangan penilaian portofolio dalam satu semester.Dan pada poin ke-4 hasil analisis penilaian sebelumnya (UH, UAS,) yang digunakan untuk keperluan program perbaikan (pengayaan dan menyempurnakan rancangan dan pelaksanaan pembelajaran) tidak dapat dilakukan oleh tiga orang guru PKn.

b. Menggunakan Berbagai Strategi dan Metode Penilaian untuk Memantau Kemajuan dan Hasil Belajar Peserta Didik dalam Mencapai Kompetensi Tertentu sebagaimana yang Tertulis dalam RPP.

Didalam proses pelaksanaan kegiatan pembelajaran strategi dan metode pembelajaran sangat penting, begitu halnya dalam proses penilaian pembelajaran. Strategi dan metode penilaian digunakan untuk memantau kemajuan dan hasil belajar peserta didik dalam mencapai kompetensi tertentu sebagaimana yang tertulis dalam rencana pelaksanaan pembelajaran (RPP). Dalam penilaian pembelajarantiga orang guru PKn SMK Negeri 4 Kendari pada aspek penggunaan berbagai strategi dan metode penilaian untuk memantau kemajuan dan hasil belajar peserta didik dalam mencapai kompetensi tertentu sebagaimana yang tertulis dalam RPP, hanya pada poin ke-1 yang dapat dilakukan oleh semua guru PKn, yakni dapat menggunakan teknik penilaian otentik (kuis,pertanyaan lisan, pemberian tugas) untuk memantau kemajuan belajar peserta didik dengan baik. Pada poin ke-2 tiga orang guru PKn kurang baik dalam menggunakan teknik penilaian (UH,UAS) yang disusun untuk mengukur hasil belajar peserta didik dalam aspek kognitif, afektif dan psikomotor. Selanjutnya pada poin ke-3 guru pertama dapat menerapkan penilaian portofolio dalam bentuk berbagai tugas terstruktur dengan baik, sedangkan guru kedua pada poin ke-3 kurang baik dalam menerapkan penilaian portofolio dalam bentuk berbagai tugas terstrukturdan guru ketiga pada poin ke-3 tidak dapat menerapkan penilaian portofolio dalam bentuk berbagai tugas terstruktur. Pada poin ke-4 semua guru PKn dapat mengikuti dengan baik dalam menggunakan alat penilaian yang sesuai dengan tujuan pembelajaran dan materi ajar sebagaimana disusun dalam RPP.

c. Memanfaatkan Berbagai Hasil Penilaian untuk Memberi Umpan Balik bagi Peserta Didik tentang Kemajuan Belajarnya

Proses pembelajaran merupakan interaksi yang terjadi antar guru dan siswa untuk mencapai tujuan. Suatu tujuan pembelajaran terjadi karena adanya usaha dari guru, sering dinamakan pengetahuan dan keterampilan (instructional effect).Sedangkan tujuan pengiring karena usaha atau potensi siswa berupa faktor kecerdasan, berpikir kritis dan kreatif (nurturant effect).Kegiatan dua pihak antara guru dan siswa dapat memberikan umpan balik. Dalam penilaian pembelajaran, pemberian umpan balik juga sangat diperlukan dengan memanfaatkan berbagai hasil penilaian guna untuk 
mengatahui perkembangan atau kemajuan belajar peserta didik. Dalam penilaian pembelajaran yang dilakukan oleh guru PKn SMK Negeri 4 Kendari pada pemanfaatan berbagai hasil penilaian untuk memberi umpan balik bagi peserta didik tentang kemajuan belajarnya, terdapat 1 poin yang belum dapat dilakukan oleh ketiga guru PKn SMK Negeri 4 Kendari, yakni pada poin ke-4 indikator penilaian pada aspek ini, yaitu guru PKn tidak dapat melaporkan kemajuan dan hasil belajar peserta didik kepada kedua orang tua siswa, teman guru dan bagi peserta didik sebagai refleksi belajar. Sedangkan dalam aspek lain tiga orang guru PKn SMK Negeri 4 Kendari dapat melakukannya dengan baik, yaitu dapat menggunakan hasil analisis penilaian untukmengidentifikasi topik/kompetensi dasar yang mudah, sedang dan sulit sehingga diketahui kekuatan dan kelemahan masingmasing peserta didik untuk keperluan remedial dan pengayaan, dan dapat menggunakan hasil penilaian untuk menyempurnakan rancangan dan pelaksanaan pembelajaran. Selanjutnya ketiga guru PKn dapat memanfaatkan hasil penilaian secara efektif untuk mengidentifikasi kekuatan, kelemahan, tantangan dan masalah potensial untuk peningkatan keprofesian dalam menunjang proses pembelajaran.

Selanjutnya untuk menghitung atau menilai kinerja guruPendidikan Pancasila dan Kewarganegaraan (PKn) yang memiliki sertifikat pendidik SMK Negeri 4 Kendari dalam penilaian atau evaluasi pembelajaran, penelitian ini menggunakan mekanisme perhitungan atau penilaian yang ditetapkan oleh PerMenpan No. 16 Tahun 2009, sebagai berikut :

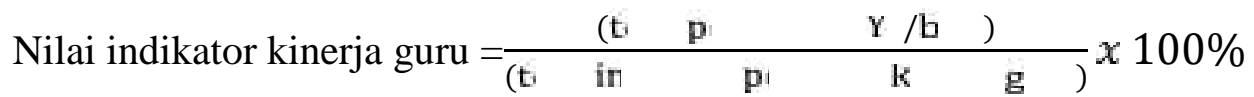

Keterangan :

$(0<\mathrm{x} \mathcal{2} 5 \%) \quad=1$ (kurang baik)

$(25 \%<\mathrm{x} \leq 50 \%) \quad=2$ (cukup baik)

$(50<\mathrm{x} \unlhd 5 \%) \quad=3$ (baik)

$(75 \%<\mathrm{x} \leq 100 \%)=4$ (sangat baik)

Berdasarkan hasil penelitian dan pembahasan maka dapat diuraikan berdasarkan rumus sebagai berikut :

a. Merancang Alat Evaluasi untuk Mengukur Kemajuan dan Keberhasilan Belajar Peserta Didik

$>$ Guru $\mathrm{I}=2 / 4 \times 100 \%=50 \%$ berdasarkan keterangan rumus maka untuk guru I memperoleh nilai 3 (baik)

$>$ Guru II $=2 / 4 \times 100 \%=50 \%$ berdasarkan keterangan rumus maka untuk guru II memperoleh nilai 3 (baik)

$>$ Guru III $=1 / 4 \times 100 \%=25 \%$ berdasarkan keterangan rumus maka untuk guru III memperoleh nilai 2 (cukup baik)

b. Menggunakan Berbagai Strategi dan Metode Penilaian untuk Memantau Kemajuan dan Hasil Belajar Peserta Didik dalam Mencapai Kompetensi Tertentu sebagaimana yang Tertulis dalam RPP.

$>$ Guru $\mathrm{I}=3 / 4 \times 100 \%=75 \%$ berdasarkan keterangan rumus maka 
untuk guru I memperoleh nilai 4 (sangat baik)

$>$ Guru II $=2 / 4 \times 100 \%=50 \%$ berdasarkan keterangan rumus maka untuk guru II memperoleh nilai 3 (baik)

$>$ Guru III $=2 / 4 \times 100 \%=50 \%$ berdasarkan keterangan rumus maka untuk guru III memperoleh nilai 3 (baik)

c. Memanfaatkan Berbagai Hasil Penilaian untuk Memberi Umpan Balik bagi Peserta Didik tentang Kemajuan Belajarnya

$>$ Guru $\mathrm{I}=3 / 4 \times 100 \%=75 \%$ berdasarkan keterangan rumus maka untuk guru I memperoleh nilai 4 (sangat baik)

$>$ Guru II $=3 / 4 \times 100 \%=75 \%$ berdasarkan keterangan rumus maka untuk guru II memperoleh nilai 4 (sangat baik)

$>$ Guru III $=3 / 4 \times 100 \%=75 \%$ berdasarkan keterangan rumus maka untuk guru III memperoleh nilai 4 (sangat baik)

Berdasarkan hasil perhitungan dengan menggunakan rumus PerMenpan No.16 tahun 2009 maka dapat diketahui bahwa tiga orang guru Pendidikan Pancasila dan Kewarganegaraan (PKn) yang telah bersertifikat SMK Negeri 4 Kendari dalam penilaian atau evaluasi pembelajaran memperoleh skor 3 (baik).

Faktor - Faktor yang Mempengaruhi Kinerja Guru PKn SMK Negeri 4 Kendari

Berdasarkan hasil penelitian faktor-faktor yang mempengaruhi kinerja guru PKn SMK Negeri 4 Kendari terbagi dua yakni faktor internal dan faktor eksternal.

\section{Faktor Internal}

faktor internal yang mempengaruhi kinerja guru pendidikan pancasila dan kewarganegaraan (PKn) antara lain, kemampuan guru, motivasi guru, tingkat pendidikan guru dan kondisi fisik guru. Adapun penjelasan dari empat faktor tersebut sebagai berikut :

1) Kemampuan guru

Untuk memiliki kinerja yang baik, guru PKn dituntut untuk memiliki kemampuan akademik yang memadai, dan dapat mengaplikasikan ilmu yang dimilikinya kepada para siswa untuk kemajuan hasil belajar siswa. Misalkan kemampuan dalam membuat perencanaan pembelajaran, pelaksanaan pembelajaran dan penilaian pembelajaran.Hal ini menentukan kinerja seorang guru kearah yang lebih baik. Kemampuan seorang guru PKn di dalam membuat perencanaan, dan melaksanakan kegiatan pembelajaran, salah satunya dalam mengelola kelas dan dalam melakanakan penilaian pembelajaran sangat mempengaruhi baik tidaknya kinerja seorang guru PKn.

2) Motivasi guru

Seorang guru PKn yang mempunyai motivasi untuk melakukan pekerjaan, berarti dalam diri yang bersangkutan sudah ada dorongan untuk bekerja. Dorongan tersebut dapat berasal dari dirinya maupun dari luar dirinya. Dorongan yang berasal dari dalam diantaranya ingin berprestasi dan berkembang, menyenangi pekerjaan serta rasa tanggungjawab. Dari luar, diantaranya ingin naik pangkat, dihargai oleh teman-teman dan 
sebagainya. Apabila semua yang diinginkan diatas dapat dicapai melalui pekerjaan, maka timbul motivasi untuk melakukan pekerjaan secara baik. Motivasi kerja yang tinggi akan menyebabkan yang bersangkutan akan lebih bersemangat, bergairah dalam bekerja. Kinerja guru PKn sangat dipengaruhi oleh motivasi. Dengan motivasi yang tinggi akan menjadikan kinerja seorang guru baik, akan tetapi jika seorang guru tidak atau kurang memiliki motivasi yang tinggi untuk meningkatkan kinerjanya kearah yang lebih baik, maka akan berdampak negatif pada kinerja seorang guru tesebut.

3) Tingkat Pendidikan guru

Tingkat pendidikan guru PKn akan sangat mempengaruhi baik tidaknya kinerjanya. Kemampuan seorang sangat dipengaruhi oleh tingkat pendidikannya, karena melalui pendidikan itulah seseorang mengalami proses belajar dari tidak tahu menjadi tahu, dari tidak bisa menjadi bisa. Selama menjalani pendidikannya seseorang akan menerima banyak masukan baik berupa ilmu pengetahuan maupun keterampilan yang akan mempengaruhi pola berpikir dan prilakunya. Ini berarti jika tingkat pendidikan seseorang itu lebih tinggi maka makin banyak pengetahuan serta ketrampilan yang diajarkan kepadanya sehingga besar kemungkinan kinerjanya akan baik karena didukung oleh bekal keterampilan dan pengetahuan yang diperolehnya. Tingkat pendidikan guru PKn sangat mempengaruhi dalam melaksanakan tugasnya. Seorang guru yang tingkat pendidikannya lebih tinggi maka dapat dipastikan kinerjanya dapat lebih baik, tetapi jika seorang guru hanya memiliki tingkat pendidikan rendah maka kinerjanya akan biasa-biasa saja.

4) Kondisi fisik (kesehatan)

Agar guru PKn memiliki kinerja yang baik maka harus didukung oleh kondisi fisik dan mental yang baik pula. Guru yang sehat akan dapat menyelesaikan tugas-tugasnya dengan baik. Oleh karenanya faktor kesehatan harus benar-benar diperhatikan. Baik atau tidaknya kinerja guru PKn, sangat dipengaruhi oleh kondisi fisik mentalnya. Guru yang memiliki kondisi badan yang sehat akan dapat menjalankan tugasnya secara baik tetapi jika kondisinya tidak baik maka akan menghambat dalam kinerjanya, dan bisa dipastikan apa yang telah direncanakan oleh guru tidak akan dijalankan dengan maksimal.

\section{Faktor Eksternal}

Faktor eksternal yang mempengaruhi kinerja guru Pendidikan Pancasila dan Kewarganegaraan (PKn) yang memiliki sertifikat pendidik SMK Negeri 4 Kendari antara lain iklim Sekolah, kepemimpinan Kepala Sekolah dan sarana dan prasarana Sekolah. Adapun penjelasan dari tiga faktor tersebut sebagai berikut :

1) IklimSekolah

Iklim di sekolah adalah produk akhir dari interaksi antar kelompok peserta didik disekolah, guru-guru dan pegawai tata usaha (administrator) yang bekerja untuk mencapai keseimbangan antara dimensi organisasi (sekolah) dengan dimensi individu. Iklim yang baik disekolah akan mempengaruhi kenerja seorang guru. Hubungan yang baik antara guru, kepala sekolah, siswa dan para karyawan sekolah akan menjadikan kinerja 
guru lebih baik dan kondisi iklim yang tidak kondusif akan mempengarahi kinerja seorang guru kearah yang kurang baik.

2) Kepemimpinan Kepala Sekolah

Kepala sekolah adalah pemimpin di lingkungannya. Karena itu kepala sekolah harus mampu menggerakkan bawahannya dengan baik sehingga tujuan organisasi yang dipimpinnya akan tercapai. Perilaku kepemimpinan kepala sekolah dapat ditunjukkan dalam gaya kepemimpinannya saat memimpin bawahannya. Kepemimpinan kepala sekolah akan mencerminkan cara-cara atau tindakan kepala sekolah dalam menggerakkan dan mengarahkan guru dalam menyelesaikan pekerjaannya untuk mencapai tujuan sekolah. Pengaruh kepemimpinan seorang kepala sekolah, akan pula mempengaruhi kinerja seorang guru. Karena seorang kepala sekolah mempunyai tugas disamping sebagai pemimpin juga sebagai manajer yang akan mengawasi, mengarahkan kinerja seorang guru kearah yang lebih baik.

3) Sarana dan Prasarana

Sarana pendidikan adalah peralatan dan perlengkapan yang secara langsung dipergunakan dan menunjang proses pendidikan, khususnya dalam kinerja guru seperti ruang kelas, meja, kursi, media pengajaran, perpustakaan dan lain-lain. Sedangkan prasarana adalah fasilitas yang tidak secara langsung menunjang jalannya proses pendidikan atau pengajaran seperti halaman sekolah, tamansekolah,ruang ibadah dan lain-lain. Sarana dan prasarana yang lengkap dan memadai dalam sebuah sekolah akan menjadikan kinerja guru PKn dapat terlaksana dengan lebih baik, akan tetapi fasilitas yang kurang dalam hali ini sarana akan menyulitkan di dalam pelaksanaan kinerja guru.

\section{PENUTUP}

\section{Kesimpulan}

Berdasarkan hasil penelitian dan pembahasan, tentang kinerja guru Pendidikan Pancasila dan Kewarganegaraan (PKn) yang bersertifikat dalam pelaksanaan tugas pembelajaran pada SMK Negeri 4 Kendari, dapat disimpulkan sebagai berikut :

1. Kinerja guru Pendidikan Pancasila dan Kewarganegaraan (PKn) yang bersertifikat dalam pelaksanaan tugas pembelajaran SMK Negeri 4 Kendari sudah baik dan sangat baik.Untuk sangat baik terutama dalam Perencanaan Pembelajaran, semua guru PKndapat membuat atau menyusun perencanaan pembelajaran sesuai indikator penilaian yang ditetapkan oleh PerMenpan No. 16 tahun 2009. Sedangkan dalam pelaksanaan kegiatan pembelajaran dan penilaian atau evaluasi pembelajaran masuk dalam kategori baik, karena tidak semua guru PKn yang bersertifikat dalam pelaksanaan tugas pembelajaranSMK Negeri 4 Kendari dapat mengikuti semua indikator penilaian yang ditetapkan.

2. Faktor - faktor yang mempengaruhi kinerja guru Pendidikan Pancasila dan Kewarganegaraan (PKn) yang bersertifikat dalam pelaksanaan tugas pembelajaran SMK Negeri 4 Kendari, yaitu faktor internal dan faktor eksternal. Faktor internal terdiri dari kemampuan, motivasi, tingkat pendidikan guru dan kondisi fisik (kesehatan). Sedangkan faktor eksternal 
terdiri dari iklim Sekolah, kepemimpinan Kepala Sekolah dan sarana dan prasarana. Dari beberapa faktor tersebut berdasarkan hasil penelitian samasama memberikan pengaruh lebih besar (dominan) bagi guru PKn dalam perencanaan pembelajaran, pelaksanaan kegiatan pembelajaran dan penilaian atau evaluasi pembelajaran.

\section{Saran}

Dari kesimpulan hasil penelitian diatas, penulis mengajukan saran sebagai berikut :

1. Para guru Pendidikan Pancasila dan Kewarganegaraan (PKn) diharapkan dapat mempertahankan dan meningkatkan nilai prestasi kerjanya dalam perencanaan pembelajaran, pelaksanaan pembelajaran, penilaian atau evaluasi pembelajaran.

2. Pengawas dan Kepala Sekolah diharapkan dapat bersinergi dalam mengawasi dan mengevaluasi kinerja guru PKn dalam melaksanakan tugasnya, baik itu dalam perencanaan pembelajaran, pelaksanaan kegiatan pembelajaran ataupun penilaian atau evaluasi pembelajaran.

3. Bagi penelitian lainnya diharapkan hasil penelitian ini dapat digunakan sebagai masukan dan acuan serta dapat menjadi rujukan dalam melakukan penelitian yang serupa dengan penelitian ini.

\section{DAFTAR PUSTAKA}

Asf, jasmani \& mustofa, syaiful. 2013. Superfisi Pendidikan. Jogjakarta: Ar-Ruzz Media

Davies, Ivor K.1987. Pengelolaan Belajar. Jakarta: Rosda Karya

Hamalik, Oemar. 1995. Kurikulum dan pembelajaran. Bandung: Penerbit Rodakarya

Peraturan Menteri Negara Pendayagunaan Aparatur Negara dan Reformasi Birokrasi (Permenpan), No. 16 Tahun 2009. Tentang jabatan fungsional guru.

Sahertian, Piet. 1997. Prinsip dan Tehnik Supervisi Pendidikan. Surabaya : Usaha Nasional.

Undang - undang Republik Indonesia Nomor 20 Tahun 2003 tentang Sistem Pendidikan Nasional

Undang - undang Republik Indonesia Nomor 14 Tahun 2005 Tentang Guru Dan Dosen

Winardi, J. 2002. Motivasi dan permotivasian dalam manajemen. Jakarta: Raja Grafindo.

Yamin, Martinis. 2013. Profesionalisme Guru \& implementasi KTSP. Jakarta: REFERENSI (GP Press Group. 